\title{
A Simple Location Index Plus Some Maps and No Apologies: Back to Basics in Exploring the Development of Links between Economic Integration and the Spatial Concentration of Industries.
}

\begin{abstract}
The analysis of the location patterns of economic activities in both Europe and the US has been addressed in an extensive literature dependent on increasingly more sophisticated techniques that arguably reframe debate away from the policy questions in focus and towards debate on the complex empirical techniques that seem to be in vogue at any given time. In part this has been a response to some clear shortcomings in the use of simple Locational Gini Coefficients. It is argued herein that simple index approaches can still retain value if augmented with intuitive reading of some relevant maps. An example of the utility of this approach is provided in relation to the location patterns of four exemplar manufacturing industries in the EU and USA.
\end{abstract}

Key words: Location Index, Data Visualisation, Economic Integration, Industrial Concentration, European Union, USA

\section{Introduction and Context}

The analysis of the location patterns of economic activities in both Europe and the US has been addressed in an extensive literature that has become heavily dependent on increasingly more sophisticated econometric and mathematical techniques. Arguably the output from this escalating complexity has not yielded readily clear and substantial value added insights. Redding (2010) provides a detailed and sympathetic survey of this work ${ }^{1}$. In part this path to sophistication has been prompted by some genuine deficiencies in the simple location indexes used to analyse these patterns (see, for example, Combes et al, 2008). Figuring large among these deficiencies is the inability to distinguish between a geography in which highly concentrated regions are randomly spread across the country and one in which these regions are located in close proximity. Recourse in econometric analysis

\footnotetext{
${ }^{1}$ Including, inter alia, Ellison and Glaeser (1997), Duranton and Overman $(2005,2008)$, Mori et al (2005) Ellison et al (2010), Marcon and Puech (2003, 2010).
} 
to spatial autocorrelation indices (such as Moran's I) has provided some purchase on the problem but may arguably deflect attention away from data comparability and other issues ${ }^{2}$.

The work presented in this study, however, contends that value added insights afforded by many spatial econometric developments is not much more than would be gained by retaining the use of a simple location index supplemented by an intuitive reading of choropleth maps featuring the spatial locations of concentrated regions i.e. just 'eyeball geography'.

The utility of this simple approach is illustrated by recourse to the analysis of location patterns for four exemplar industries in the United States and the European Union. Are certain industries in the EU less (or even more) spatially concentrated than their American counterparts? Indicators measuring the regional concentration of industries (Balassa Indices or Location Quotients) are computed and enriched by the use of data visualisation methods.

A second objective is to investigate the reasons for potential differences in the underlying degree of concentration of these industries - based on their distinctive characteristics and spatial economic theory. From these insights we derive an assessment of the impact of economic integration on industries' location behaviour - based on the a priori assumption that the US market is more integrated than the common market of the European Union. In this sense, the United States is characterised (with many obvious caveats) as a kind of 'natural experiment' for a large integrated market.

The organisation of this paper is as follows. The literature framing the study is briefly reviewed in the next section. The modes of analysis employed are detailed in Section 3 with results set out in the following section. Section 5 presents a discussion of these findings with some concluding remarks offered in the final section.

\section{Spatial Economic Thinking: A Brief Retrospect}

Spatial economics deals with the emergence, existence and changes found in spatial economic structures (Schöler, 2005). While von Thünen (1826) investigated the question of the optimal distance to the place of consumption for different forms of agricultural land

\footnotetext{
${ }^{2}$ This is not to say that the more sophisticated spatial econometric approach is not invaluable in relation to helping guide, say, funding allocation policy, in relation to health differences in small areas and regions within a given country.
} 
utilisation, this train of thought was steered onwards by others, most prominently Alfred Weber (1909). He identified the three categories of costs that principally determine the optimum location for a production plant: transportation, labour and our key study focus agglomeration.

Since the early 1990s, spatial economics witnessed a renaissance, widely subsumed under the label New Economic Geography (NEG) (Jovanovic, 2007). What NEG authors have in common is summarised in Eaton and Lipsey (1997): they reject the neoclassical competitive vision of economy, which does not accommodate lumpiness (indivisibility). This implies that NEG authors put more emphasis on economies of scale, whereas neoclassical theory suggests that comparative advantages are the main driving force behind location choice. Additionally, specificity of physical and human capital and diversity of tastes and preferences are introduced. Overlaying this thinking is the notion that NEG is a more evolutionary theory of economic behaviour which is better in dealing with dynamics, such as technological and structural change.

Krugman (1999) investigated the rationale behind agglomeration (clustering) and dispersion (spread) of activities. He found that there are centripetal (or snowball/herding forces) and centrifugal forces working against each other. The former work towards an equilibrium of agglomeration, whereas the latter test this equilibrium for its stability. In Table 1, Krugman's major agglomeration and dispersion forces are outlined. Most of the insights considering agglomeration forces seem to derive from Marshall (1890) and are rather standard, whereas the work around 'dispersion forces' firmly reflect Krugman's typology.

\section{Agglomeration Forces}

- Market size effects (linkages): A large number of suppliers to source inputs from implies a lower price level (upstream), whereas the proximity of a large number of consumers makes it easier to sell products (downstream).

- Thick labour markets: An industrial concentration facilitates finding workers with specialised skills and, vice versa, employees find it easier to find work.

\section{Dispersion Forces}

- Immobile factors: Often production must go to where (immobile) workers, land and natural resources are. On top of that, proximity to peripheral consumers in a highly dispersed market has to be kept.

- Land rents: Increased demand for land and workers drives up factor prices and therewith discourages further concentration. 


\begin{tabular}{|ll|}
\hline $\begin{array}{l}\text { neighbourhood effect the spread and } \\
\text { exchange of information is facilitated. }\end{array}$ & $\begin{array}{l}\text { include costs that derive from } \\
\text { congestion, commuting and pollution. }\end{array}$ \\
\hline
\end{tabular}

Table 1: Agglomeration and Dispersion Forces (Source: Krugman, 1999)

In the parallel business literature, Porter (1998, p. 78) defines a cluster as the "geographic concentration of interconnected companies and institutions in a particular field". These bodies include suppliers of specialised inputs, providers of infrastructure, a sophisticated customer base, a pool of skilled employees, related industries providing complementary products and governmental and other institutions such as universities, trade associations and think tanks. Proximity to all these facilitate the flow of information, enabling a more productive use of inputs through continual innovation. The self-reinforcing circle that derives from a cluster is illustrated in Figure 1. Cluster emergence can be rooted in historical circumstances, unusual local demand, the existence of related industries, the location of one or two innovative market giants, or in pure chance. Overlaying these factors is policy aimed at increasing a region's potential to attract clusters.

Ottaviano (2004) explains where firms might locate if countries differ in terms of market size. In the case of a two-country economy, the location with larger local demand succeeds in attracting production according to the home market effect. In the more realistic case of more than two countries, it is the overall market access (i.e. the centrality) that matters.

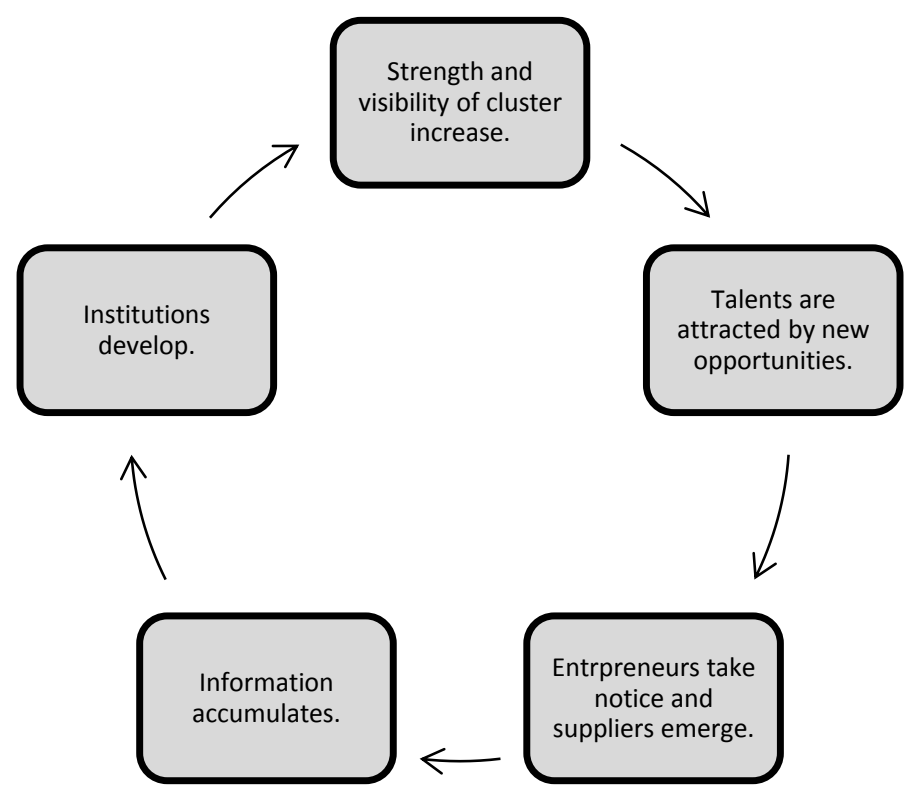

Figure 1: Self-reinforcing Circle of a Cluster (Source: Porter, 1998) 


\section{Analytical Approach}

Location Quotients (Balassa Indices) are computed for four focus sectors and are also analysed qualitatively with the aid of choropleth maps and metrics such as Lorenz Curves and Gini Coefficients. Whereas the latter is a quite common approach in the NEG literature, the former is manifestly far less common.

The included sub-industries for three NAICS sectors are almost identical. For the fourth (transportation equipment manufacturing), two NACE sectors have had to be merged, since the EU classification system makes a more detailed distinction.

In order to facilitate international comparability of regions, the Organisation for Economic Co-operation and Development (OECD, n.d.) has developed a division of its member countries into Territorial Levels (TLS). Their sizes are influenced by both the surface of the area and its population - always subject to political geography. These levels are officially established and relatively stable. A downside of the political boundaries on geographical division is that both population and surface of the regions may differ to a great extent. In the United States, for example, the state populations range from 37 million Californians to less than 600,000 people living in Wyoming. Results can be biased through this inequality. In spite of this specific concern, the OECD system is applied due to a lack of alternatives.

Some potential problems arise with the inclusion of the (mostly Central European) "new" EU member states. This difficulty is rooted in three reasons. Firstly, they have shown very irregular supply patterns in regional data throughout the analysed time frame, which might make a comparison impossible. Secondly, these Central European states are very heterogeneous in income in comparison to any of the US states (and the EU15 members), which might make a comparison implausible. Lastly, the inclusion of these states into the Union took place in 2004 and 2007. During the rather short time period since then, they might not have been able to open up and integrate into the common market sufficiently, which would make an unqualified comparison inappropriate. For all these reasons, it was decided to restrict the investigation to the $15 \mathrm{EU}$ member states before 2004. A positive side effect of this restriction is that the EU15 population of just below 400 million is more comparable to the US population of around 300 million inhabitants. 
Practicality and availability of data restrict the investigation to the large Territorial Level 2 (TL2). In the United States, these TL2 regions equal the states. In the European Union, on the other hand, they are a mixture of NUTS1 and NUTS2, depending on the country. Table 2 summarises each country's specific subdivisions. It has to be noted that an average TL2 region in the EU15 covers $2,277 \mathrm{~km}^{2}$ and is populated by 2.8 million inhabitants whereas an average US state has a surface of $17,894 \mathrm{~km}^{2}$ and a population of 5.8 million. This discrepancy creates a bias towards lower concentrations (and therewith the appearance of dispersion) in the United States possible due to the fact that the work force in a highly specialised sub region of a large area can be more than outweighed by the large employment base of the entire area and therefore appears diminished.

\begin{tabular}{|c|c|c|c|}
\hline OECD Country & $\begin{array}{l}\text { Surface } \\
\left(100 \mathrm{~km}^{2}\right)\end{array}$ & Population (2005) & Territorial Levels 2 \\
\hline Austria (AT) & 83 & $8,236,000$ & 9 Bundesländer \\
\hline Belgium (BE) & 30 & $10,479,000$ & 3 Régions \\
\hline Denmark (DK) $)^{3}$ & 43 & $5,404,000$ & 5 Regioner \\
\hline Finland $(\mathrm{FI})^{4}$ & 304 & $5,246,000$ & 5 Suuralueet \\
\hline France $(F R)^{5}$ & 544 & $60,996,000$ & 22 Régions \\
\hline Germany (DE) & 357 & $82,469,000$ & 16 Bundesländer \\
\hline Greece (GR) & 131 & $11,104,000$ & 4 Groups of Development \\
\hline Ireland (IE) & 68 & $4,159,000$ & 2 Regional Authority Regions \\
\hline Italy (IT) & 295 & $58,607,000$ & 21 Regioni \\
\hline Luxembourg (LU) ${ }^{6}$ & 3 & 457,000 & 1 State \\
\hline Netherlands (NL) & 34 & $16,320,000$ & 4 Landsdelen \\
\hline Portugal $(\mathrm{PT})^{7}$ & 92 & $10,549,000$ & 7 Commissaoes de Coordenacao Regional \\
\hline Spain (ES) ${ }^{8}$ & 506 & $43,733,000$ & 19 Communidades y Ciudades Autonomas \\
\hline Sweden (SE) & 410 & $9,030,000$ & 8 Riksområden \\
\hline United Kingdom (UK) & 243 & $60,228,000$ & 12 Government Office Regions \\
\hline European Union (EU15) & 3,143 & $387,017,000$ & 138 TL2 Regions \\
\hline United States (US) & 9,126 & $296,507,000$ & 50 States (+ 1 District) \\
\hline
\end{tabular}

\footnotetext{
${ }^{3}$ Due to data availability, Denmark's five regions had to be treated as one country.

${ }^{4}$ Finland's minor island Åland was added to mainland's Etelä-Suomi.

${ }^{5}$ Due to distance from the European mainland, France's oversea territories were not considered.

${ }^{6}$ Due to data availability, Luxembourg had to be taken out of the investigation. (Henceforth: EU or EU14 = EU15 without Luxembourg)

${ }^{7}$ Due to distance from the European mainland, Portugal's Regioes Autonomas, Acores and Madeira, were not considered.

${ }^{8}$ Spain's Northern African territories Ceuta and Mellila were added to Southern Spain's Andalucia.
} 
Originally, the Balassa Index (BI) (Balassa, 1965) was used to measure relative export performances by country and industry to detect comparative advantages. However, it can also be used for indices other than exports and computed as:

$$
B I=\frac{\text { RegionalIndustryValue }}{\text { NationalIndustryValue }} / \frac{\text { RegionalTotalValue }}{\text { NationalTotalValue }}
$$

A BI greater than 1 is a sign of a region providing a relatively large part of an industry's overall national value; a $\mathrm{BI}$ smaller than 1 reflects sub-proportionate importance of a region in total industry output. ${ }^{9}$

A decision about which economic indicator to use in the index is necessary at this stage. Employment figures are used in this analysis, highlighting the link between industries and their respective working population.

For the United States the Quarterly Census of Employment and Wages (QCEW) is utilised. For the European Union, Eurostat's (n.d.) Structural Business Statistics (SBS) are deployed. A majority of Bls around the national average value of 1 would indicate that an industry is dispersed, whereas a BI structure with some very high and a lot of very low values would indicate agglomeration.

One way to analyse the computed LQs is proposed by O'Donoghue and Gleave (2004). Using so-called standardised location quotients, they determine critical values for econometric significance testing. The major caveat and indeed flaw in adopting such an approach for our work is the implicit assumption of a normal distribution, as highlighted by Tian (2013). Accordingly we persist with the more basic approach, characterised by the use of Lorenz Curves and Locational Gini Coefficients (Porter, 2003; Midelfart-Knarvik et al., 2002). Amiti (1999) explains step by step how to compute and interpret the coefficients.

While this quantitative analysis of industrial concentrations delivers a fairly objective comparison between concentrations of same industries across regions and of different industries within and across regions, it suffers from one major weakness in detecting clusters (as does O'Donoghue and Gleave's (2004) approach): the location of regions is not considered. An industrial geography with two highly concentrated regions at opposite ends

\footnotetext{
${ }^{9}$ A slightly different approach to express the exact same relationship is the use of Location Quotients (LQs) (cp. Bureau of Economic Analysis, n.d.)
} 
of the continent cannot be distinguished from one with two neighbouring regions with high industry concentration. The smaller the observed geographical area, the more likely it is that a cluster might spread across regional borders.

To address this problem, an interactive graphical tool, the OECD eXplorer, is used to map regional statistics. Clearly, many regions with high industry concentration in proximity to each other indicate a higher spatial concentration than many regions with just high industry concentration spread across the continent.

\section{Results}

The Locational Gini Coefficients (Figure 2) deliver a first impression of quite highly concentrated apparel industries in both reference areas with a notably higher degree of concentration in the European Union (0.62) than in the United States (0.57). A closer look at the Lorenz Curves offers insights on the source of this concentration. In the EU, the regions with the highest industry concentration, representing $70 \%$ of overall employment in the apparel industry, make out roughly $20 \%$ of total employment across all industries. In the United States, the concentration is slightly less extreme: the top $70 \%$ of industry employment are matched when regions providing around $30 \%$ of total employment are considered. The distribution of employment in apparel manufacturing is more in line with overall employment in the United States than in Europe.

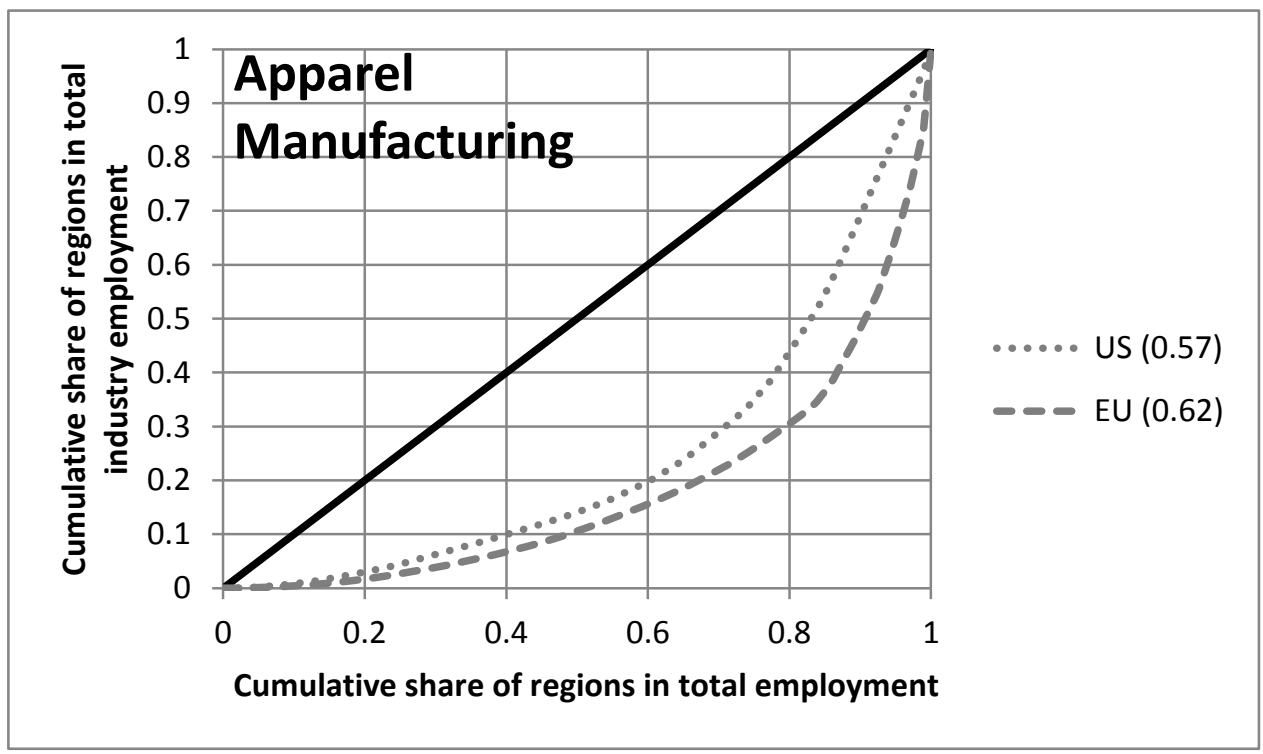

Figure 2: Lorenz Curves and Gini Coefficients, Apparel Manufacturing (Source: authors own calculations based on QCEW, n.d.; Eurostat, n.d.) 
The maps (Figure 3) offer insights about the location of those regions that are highly concentrated. In the EU, there are a number of regions characterised by $\mathrm{BI}$ values higher than 2.5 (dark shading). Interestingly, the location of these regions is that they are all within the Southern European states of Greece, Italy, Spain and Portugal. It can be seen that the Portuguese apparel cluster even reaches from Norte (PT) across the border to Galicia (ES). Quite strikingly, there is not a single region with a Balassa Index higher than 1.5 in any country north of these four. To offer an interpretion: there is not a single region in Central and Northern Europe, in which the apparel industry is significantly more concentrated than in the EU average. In Southern Europe (except France), on the other hand, this is the case in a majority of regions.

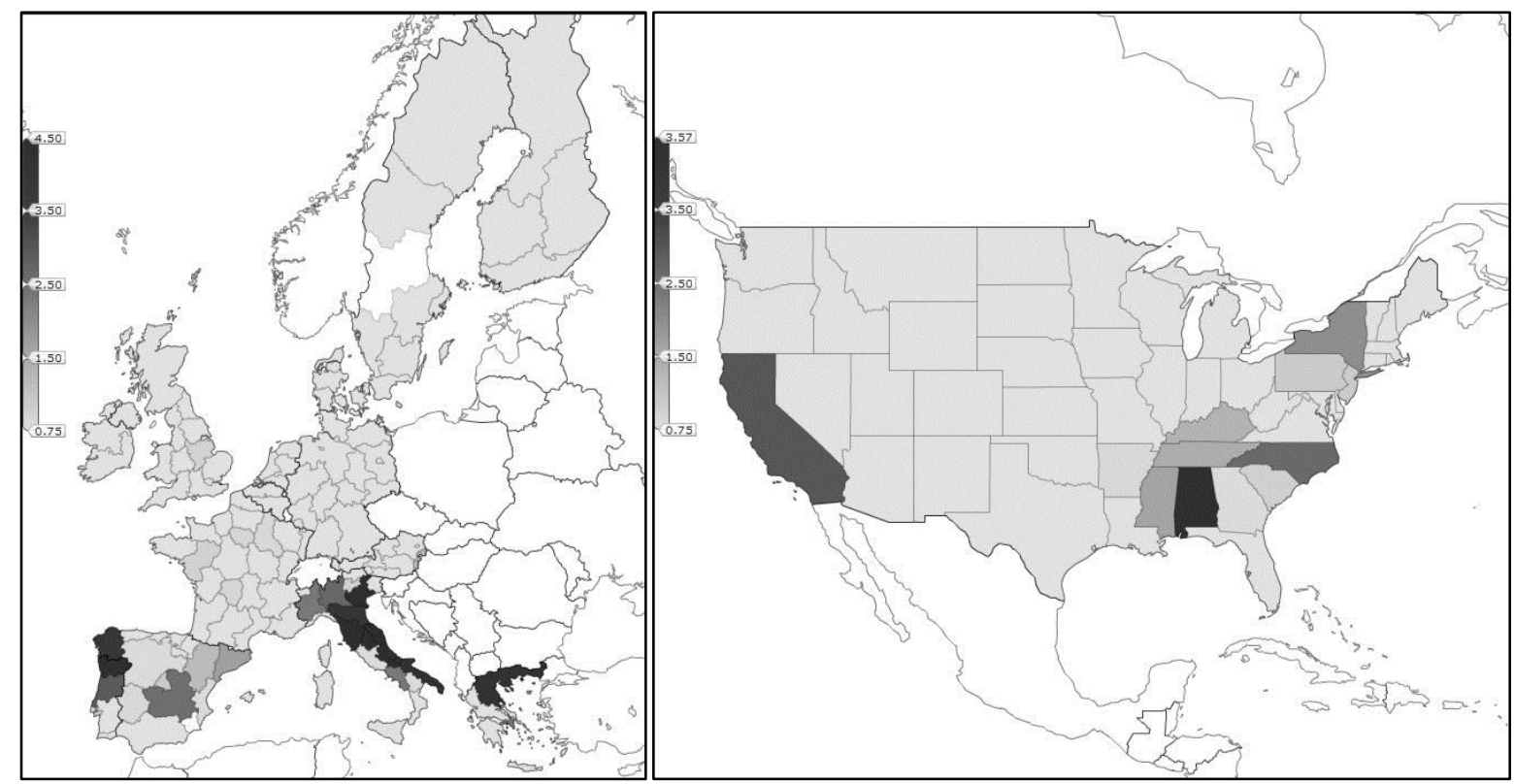

Figure 3: OECD eXplorer Maps, Apparel Manufacturing (Source: authors own calculations based on QCEW, n.d.; Eurostat, n.d.)

In the United States, a co-location of states with a rather high apparel industry concentration is observable in the Southern States as well. Alabama and North Carolina provide Bls higher than 3.5 and 2.5, respectively. Mississippi, Tennessee and Kentucky add to this cluster with employment concentrations higher than 1.5. On the West Coast, California is characterised by a concentration higher than 2.5. New York State represents an exception, being the only Northern State with a BI higher than 1.5.

The apparel industry is more agglomerated in Europe than in the United States, both from an aspatial and from a geographical point of view. Lorenz Curves and Gini Coefficients indicate that there are more highly specialised regions (with Balassa Indices higher than 2.5) 
in Europe than in the USA. The maps illustrate that all of these clusters are found in the southernmost countries (Portugal, Spain, Italy and Greece). In the United States, the cluster in the South is less pronounced and subject to competition from the West Coast (California) and the Northeast (New York).

In order to detect the reasons for the higher degree of agglomeration in Europe's apparel industry, one must discern what companies locating in Southern Europe might seek. A fairly obvious advantage of the Southern European states is the lower income level (cp. Krugman, 1999: Dispersion force 2). 25 \% of all EU15 citizens live in so-called "Objective 1" regions regions whose GDP per capita is less than $75 \%$ of the EU average and are therefore eligible to structural funding by the EU. In the United States only the inhabitants of Mississippi and West Virginia - less than $2 \%$ of the population - would be affected by such an allocation (Puga, 1999). Porter (1998) finds that in low-income economies, clusters tend to be more natural-resource or labour intensive and mentions the apparel industry in Portugal as an example. Navaretti et al. (2001) identify lower-cost regions with proximity to the major markets as the optimal location for the apparel industry - a description that fits well for most of Southern Europe.

In the United States apparel industry, lacking the substantial European wage differences as a location factor, the influence of supply chain linkages is obvious (cp. Krugman, 1999: Agglomeration force 1). Navarra et al. (2001) observe an increasing tendency towards vertical integration along the supply chain, increasing the pressure towards agglomeration. The cluster in the Southern States is likely to be a legacy of the South's historical cotton industry. A large number of suppliers represent an upstream linkage that lowers the price level for inputs. The competition from California and New York State, on the other hand, is arguably explained from the other side of the supply chain. Both California and even more New York represent centres of apparel retailing. Proximity to these centres with their vast consumer markets facilitates marketing and selling apparel.

If the basic assumption that economic integration is more pronounced in the United States than in the European Union is valid, this seems not to be a decisive factor determining agglomeration in the apparel industry. Instead, substantial wage differentials within the European Union seemingly outweigh the importance of economic integration, leading to stronger industrial concentration in the European Union's South than in any US region. 
The primary metal industry paints a picture of high industry concentration for both European Union and United States with the European Locational Gini Coefficient (0.55) beating the US Coefficient (0.50). The Lorenz Curves (Figure 4) illustrate that the distribution of employment is rather similar in the regions with the highest ind ustry concentration. The regions covering the top $50 \%$ of employment in the metal industry account for roughly $20 \%$ of total employment in both Europe and America. The difference between EU and US Gini Coefficients is rooted in regions with relatively low employment in metal manufacturing. The lowest $40 \%$ of total employment is matched by only $10 \%$ industry employment in Europe, but by $15 \%$ in the United States. This indicates that the European Union has more regions with a relatively low concentration of primary metal manufacturing.

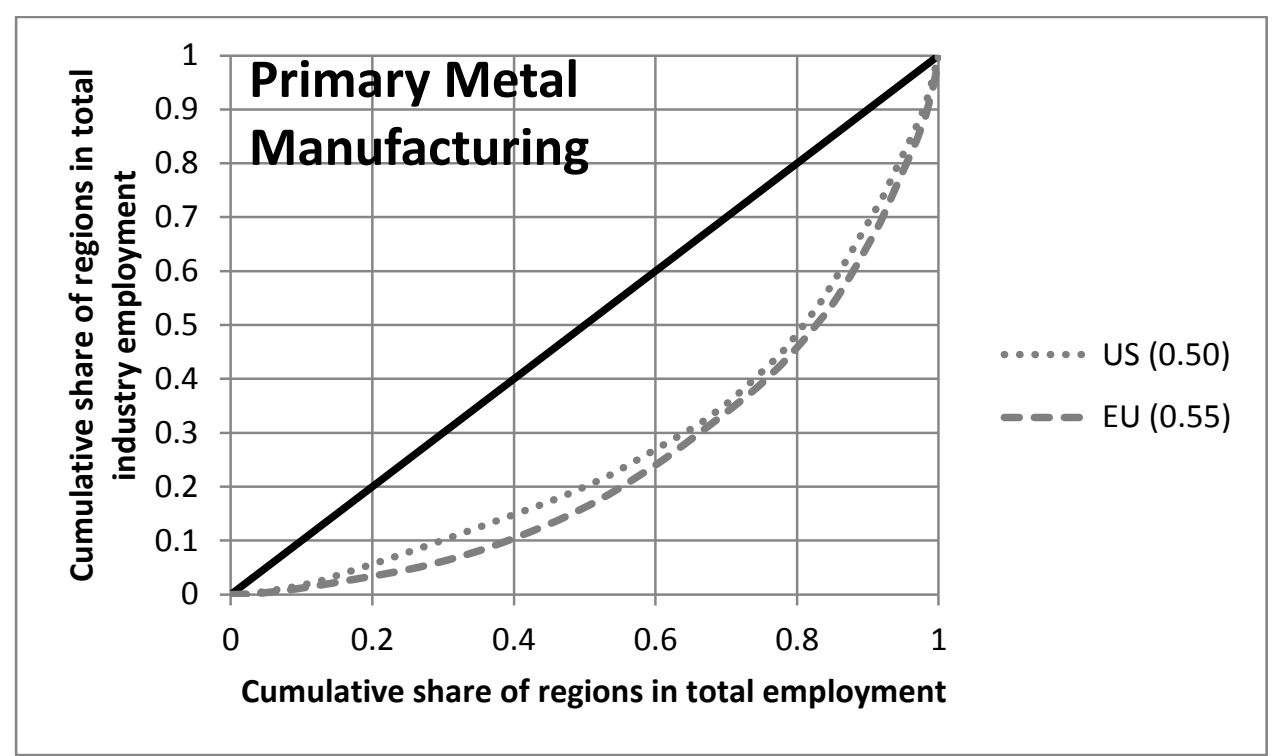

Figure 4: Lorenz Curves and Gini Coefficients, Primary Metal Manufacturing (Source: authors own calculations based on QCEW, n.d.; Eurostat, n.d.)

The maps in Figure 5 offer insights concerning the locations of the regions with specifically high employment in the metal sector. In Europe, two strong clusters can be identified - one at each end of the continent. In the North of Scandinavia, a metal cluster spreads across the border between Finland and Sweden, covering four regions with Balassa Indices higher than 2.5. The other cluster is located along the Northern Coast of Spain, also spreading across four regions with Bls above 2.5. It is worth noting that there are three more minor regions with index scores above 4.5, two of them being in Northern Italy and one in Germany. These regions have obviously managed to attract companies in the metal industry in spite of their locations being relatively remote from the two major clusters. 


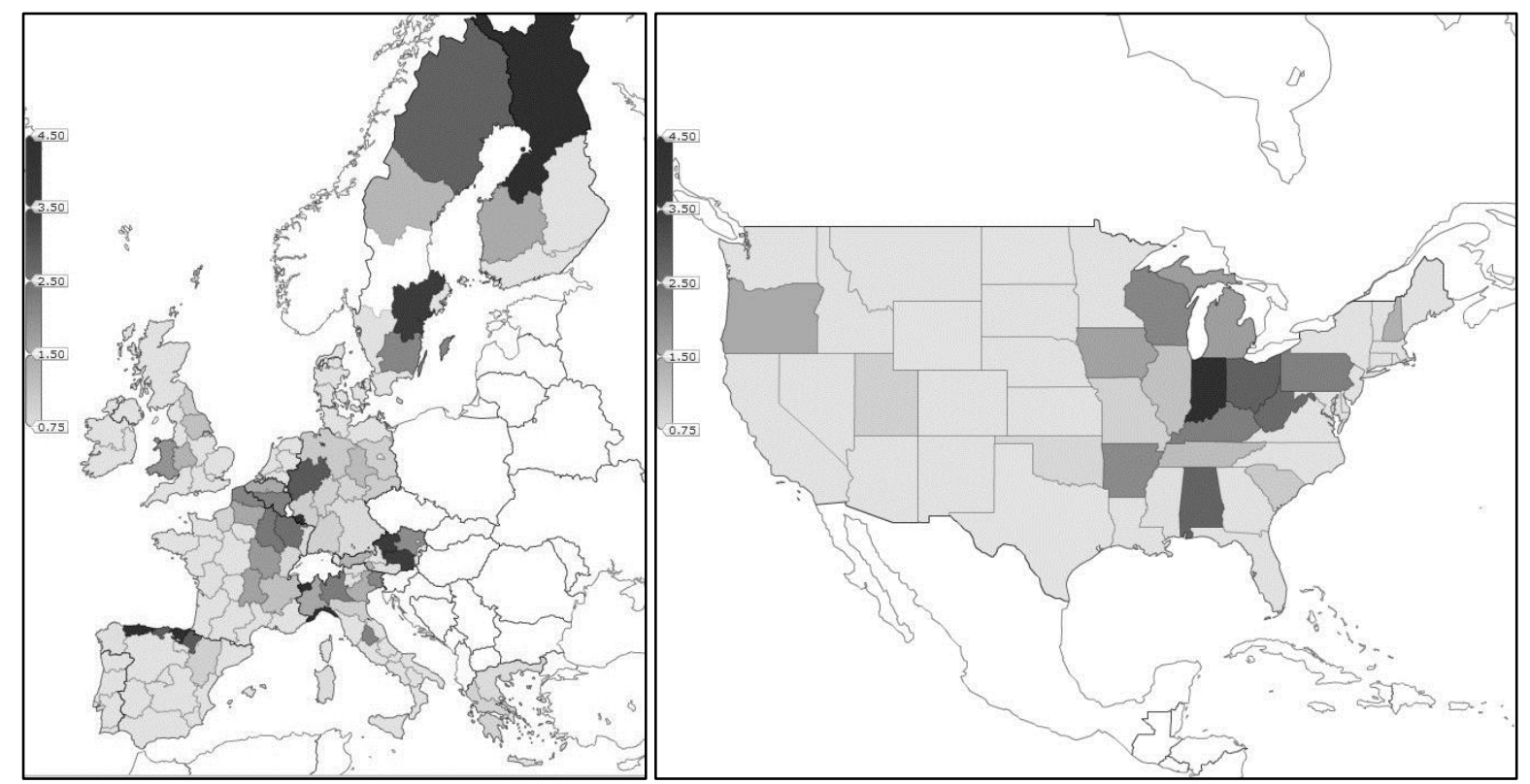

Figure 5: OECD eXplorer Maps, Primary Metal Manufacturing (Source: authors own calculations based on QCEW, n.d.; Eurostat, n.d.)

In the United States, a metal cluster is found to be spreading from the Midwest to the South, covering Indiana (4.70), Ohio (2.83),West Virginia (2.63) and Alabama (2.80). Most of the other above average Bls can be found in states in the Midwest, in proximity to the States mentioned above. The West and Southwest, on the other hand, are characterised by low to average industry concentration.

It is striking that the location of the metal industry in Europe is contrary to what the home market effect (cp. Ottaviano, 2004) might suggest. Instead of locating centrally and making use of advantages in overall market accessibility, the metal sector locates in the Union's periphery. In the apparel industry, this choice was explained by advantages through low labour costs due to an over proportional weight of unskilled labour. A similar argumentation can be constructed for the metal industry.

Feenstra et al. (1998) suggest a complementary explanation. In an empirical study on international trade, they discover that the home market effect is reversed in case of homogeneous goods and the presence of barriers to entry (e.g. due to resourcedependency). Due to intrinsic homogeneity, product differentiation is hard to achieve and therefore the importance of costs as a factor increases, favouring the low income periphery again. Kangasharju (2001) provides an additional explanation. He observes a life cycle for industries that has several firm-specific effects. Most importantly, the degree of innovativeness decreases in the late stages of this life cycle. He observes that the metal 
sector exhibited its major breakthroughs in the early industrial revolution and therefore suggests classifying the industry as being in a rather mature and late stage of its life cycle. Knowledge spillovers as a major agglomeration force therefore lose in importance, making location in the periphery relatively more attractive.

It has to be noted that the orientation towards the periphery is not observable in the United States' metal sector. On the contrary: the United States Census Bureau identifies the median centre of US population to be in Indiana, the state with the highest of all measured BIs. Again, the absence of regions with considerable advantages in terms of labour costs might be a reason for the differences in comparison to the European Union's metal sector's location pattern. On top of that, proximity to downstream parts of the supply chain, such as the automobile sector in Michigan seems to be important. Below the line, the spatial concentration of the industry in Europe is higher than in America, suggesting that the higher degree of economic integration in the United States does not play a crucial role in this sector either.

The differences in the computer and electronic product sector are the most distinct of all observed sectors. Whereas the sector is somewhat agglomerated in the United States with a Locational Gini Coefficient of 0.43, it is highly concentrated in the European Union, exhibiting a Locational Gini Coefficient of 0.67 (Figure 6). The most involved regions in the European Union, possessing about $90 \%$ of industry employment, only account for $60 \%$ of total acrossindustry employment. In the United States, on the other hand, the figure corresponding to $60 \%$ of total employment is $80 \%$ of industry employment. The distribution of employment in the sector is more in line with overall employment in America than in Europe. From the very flat slope around the origin of the EU Lorenz Curve it can be seen that there must be a disproportionately large number of regions with extremely low Balassa Indices. The bend at the very end of the Curve indicates the presence of some regions with extraordinarily high employment in the computer sector. 


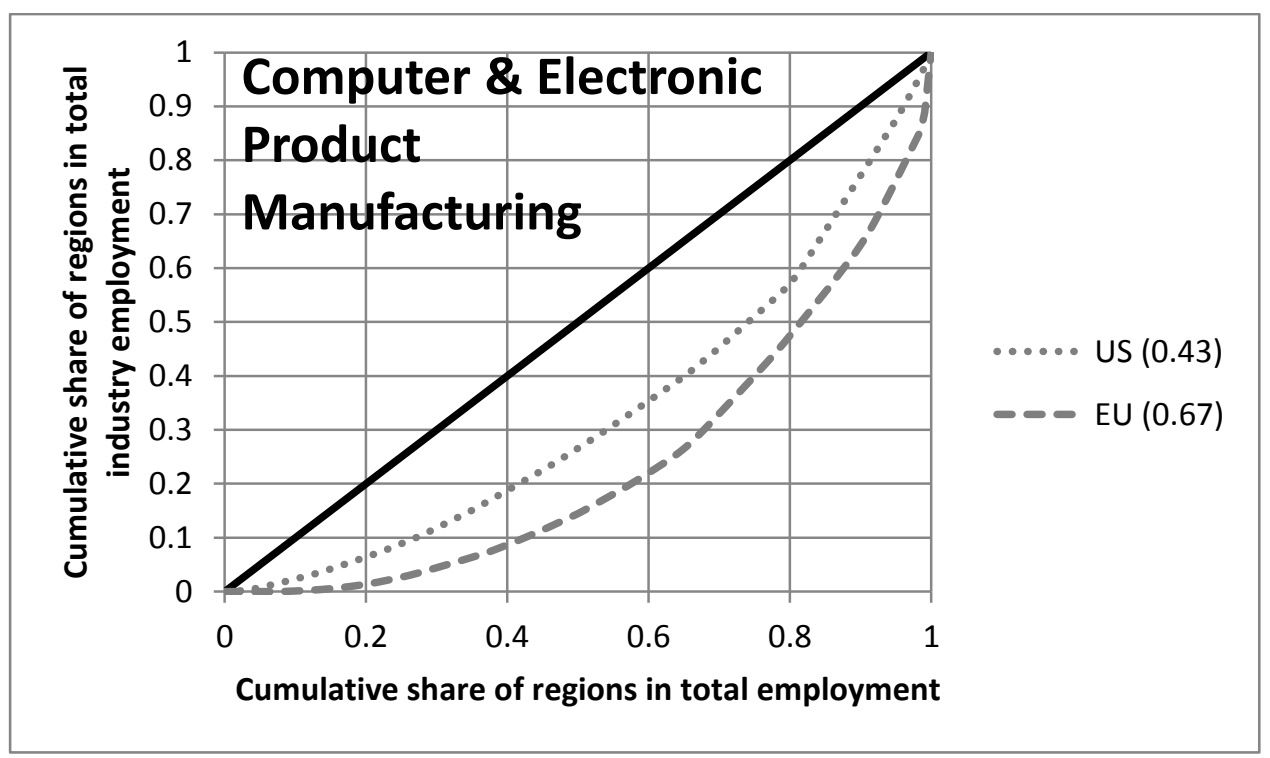

Figure 6: Lorenz Curves and Gini Coefficients, Computer \& Electronic Product Manufacturing (Source: authors own calculations based on QCEW, n.d.; Eurostat, n.d.)

Again, the respective maps (Figure 7) provide information about the location of the identified regions. In the European Union, a very strong cluster in the computer sector can be identified in and around Ireland. It covers both the Republic of Ireland (with Bls of 12.02 and 3.87) and Northern Ireland (5.85) and even reaches into Scotland (2.53). The tiny Italian region Valle d'Aosta provides a noteworthy Balassa Index of 11.57. Only two other regions feature Indices higher than 2.5: Bayern (DE) with an Index of 2.65 and Alsace (FR) with 2.70. On the other side, 21 regions report no employment in the sector at all or fail to deliver a figure and are therefore set to be zero. Even though from the location of these regions (mainly in Spain and Sweden) and their surroundings it is fair to assume that their contribution to the industry is not significant, a bias towards an overstated agglomeration might have thus been generated in this specific case. 


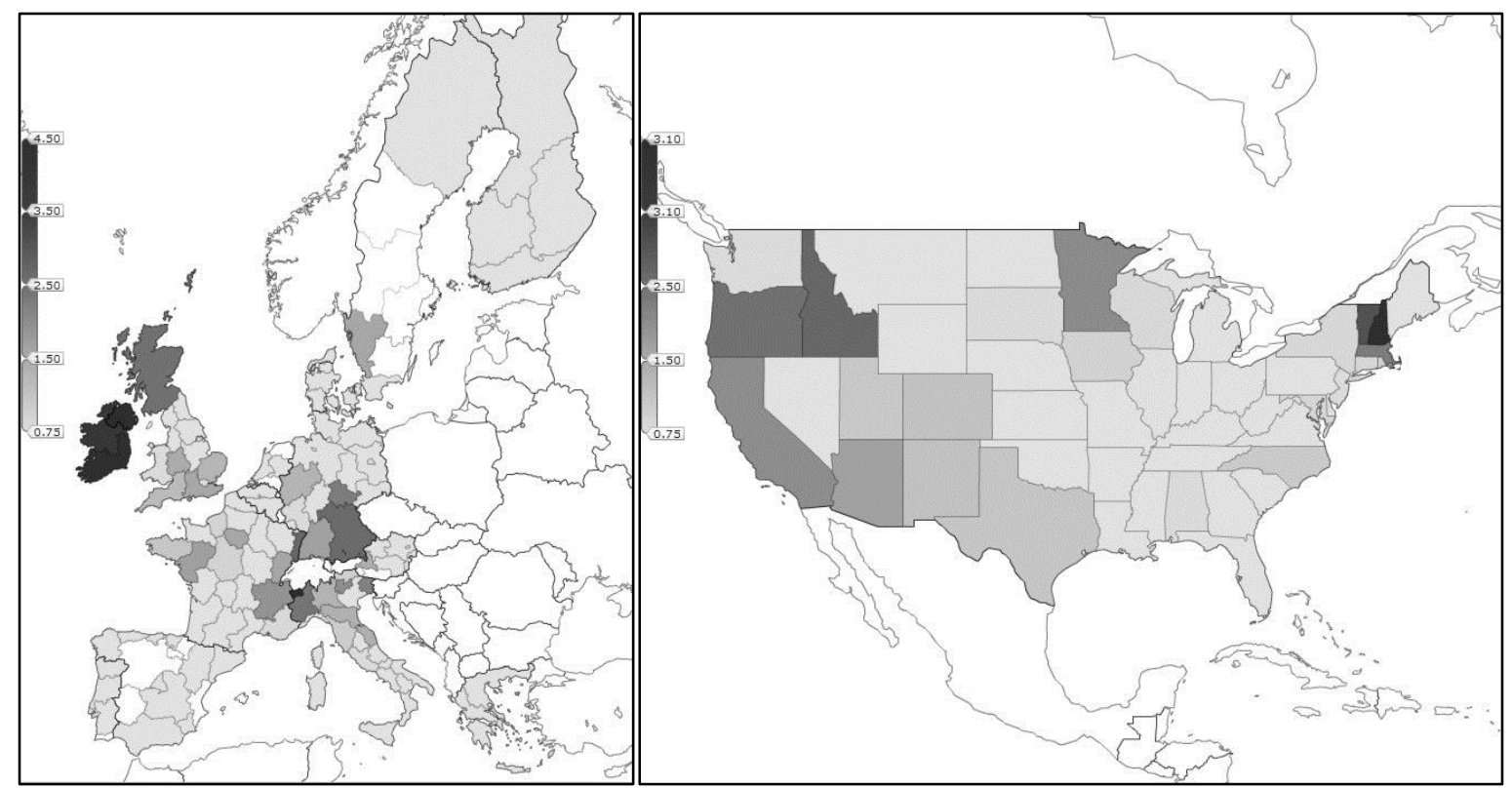

Figure 7: OECD eXplorer Maps, Computer \& Electronic Product Manufacturing (Source: authors own calculations based on QCEW, n.d.; Eurostat, n.d.)

In the United States, the location pattern of the computer industry is different from that of many other sectors. The usually rather strong Midwest is under-represented. Instead, two pairs of neighbouring states report Balassa Indices above 2.5: New Hampshire (3.10) and Vermont (2.86) in the Northeast and Idaho (2.62) and Oregon (2.51) in the Pacific Northwest. It is noticeable that, contrary to all other industries, most of the states with above average industry concentration are situated in the western half of the country. Quite surprisingly, the Californian computer cluster around Silicon Valley does not appear to be as significant as expected. Even though the co-location of two states in each case with significantly high Bls suggests agglomeration, the Indices are strikingly low in comparison to the European Union's front runners.

The computer industry is characterised by rapid and sustained technical innovation. Consequently, speed and innovativeness are keys to success. According to spatial economics, these innovative high-velocity industries are the ones most likely to cluster. Proximity to competitors makes it possible to learn early about evolving technology; proximity to a sophisticated consumer base enables to detect trends more quickly; proximity to suppliers provides the capacity and flexibility to react rapidly (Porter, 1998).

The Irish ICT cluster is a prime example of a young dynamic cluster that has been catalysed by public policies. The industry has risen in the 1990s, a decade with average annual GDP growth rates of $8 \%$ and a total increase in the number of jobs of nearly $50 \%$ in Ireland 
(Green et al., 2001). The growth was essentially catalysed by exports with a staggering $90 \%$ share in national GDP - a remarkable ratio for an economy that is situated in Europe's periphery. The ICT industry carries the lion's share of this growth, covering a third of Irish exports. Software products are the leading force in the Irish ICT sector, for which Ireland, with a global share of $34 \%$, is world market leader (Green et al., 2001). The manufacturing of personal computers and components and a teleservices and call centre industry make the cluster complete.

As already hinted at, the rise of the Irish ICT cluster is not purely based on free market forces. Rather, a deliberate strategy by the Irish Industrial Development Agency (IDA) succeeded in attracting immense-scale Foreign Direct Investment (FDI), which accounts for around $80 \%$ of manufacturing exports. With only $1 \%$ of EU population, Ireland achieved to gain 23 \% of all FDI and 55 \% of computer software FDI in Europe in 1997 (Green et al., 2001).

An important factor in the attraction of FDI, besides a lucrative tax system and structural funds by the EU, was a sophisticated human resource base. In an IMD World Competitiveness Report, Ireland ranked first for the fit between the educational system and the needs of a competitive economy (Green et al., 2001), especially with a high output of third-level graduates in computer science. This represents a crucial difference between Ireland and many other peripheral economies that attract industries by low wage rates rather than a highly qualified work force. For Ireland's ICT sector, the strategy could not have paid out more.

In the United States, on the other hand, the tendency towards clustering in the ICT sector seems to be less pronounced. The legendary Silicon Valley in California does not appear as significant as expected in the present analysis, which can be partly explained by the vast size of the State of California. Even a highly ICT concentrated Silicon Valley region would seem to be relatively less significant per capita by virtue of having a huge population of 37 million. The observable cluster in New England, on the other hand, is another clue for the importance of a highly sophisticated work force, which, without doubt, is produced in New England's various Ivey League Universities. The fact that highly specialised Ireland is on its way to outperform the United States in terms of ICT market shares is a sign for the importance of clustering in the knowledge-based ICT sector. 
A study by Midelfart-Knarvik and Overman (2002) suggests that Ireland is the only country that has become more specialised as a result of state and EU expenditures. This suggests that through substantial investments in education, Ireland was able to reinforce its comparative advantage.

The transportation industry is the only observed sector, for which Lorenz Curve and Locational Gini Coefficient signal a higher degree of industry concentration in the United States (0.48) than the European Union (0.43) (Figure 8). Whereas the Lorenz Curves look rather similar throughout most of the distribution, a gap appears in the region between $30 \%$ and $60 \%$ of industry employment. This gap indicates that there are relatively more regions in the USA that are characterised not by extreme industry concentration, but by a moderately increased level around Balassa Indices of 2.

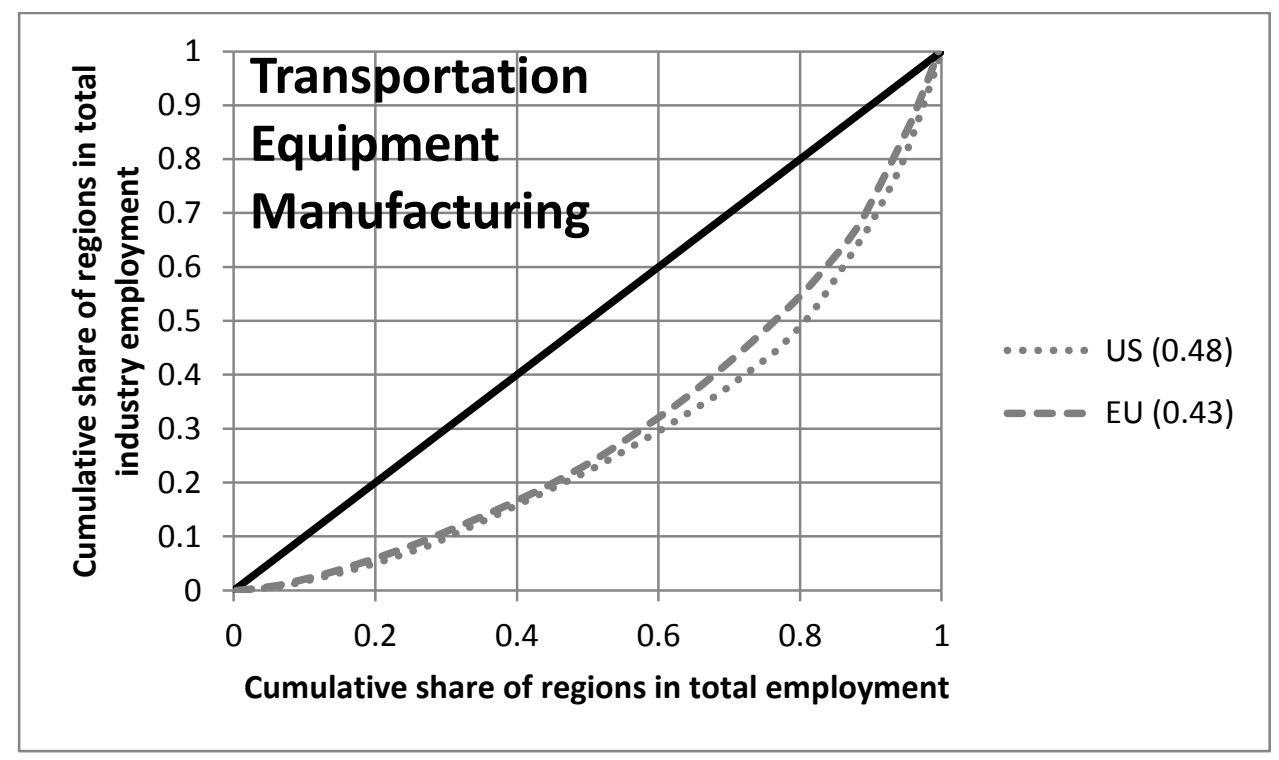

Figure 8: Lorenz Curves and Gini Coefficients, Transportation Equipment Manufacturing (Source: authors own calculations based on QCEW, n.d.; Eurostat, n.d.)

Scrutiny of the maps (Figure 9) shows the relative importance of the automobile industry in the transportation sector. Six out of the European top ten regions in terms of industry concentration are found in Germany. Apart from the small Stadtstaaten Bremen and Hamburg and tiny Saarland, three large Bundesländer show significant industry concentration with Balassa Indices above 2.5: Bayern (which happens to be home to Audi in Ingolstadt and BMW in München), Baden-Württemberg (home of Mercedes Benz and Porsche in and around Stuttgart) and Niedersachsen (where Volkswagen has its headquarters in Wolfsburg). In Sweden, Västsverige (including Volvo's headquarters in Göteborg) exhibits a significantly high $\mathrm{BI}$ of 4.12. It is worth noticing that the big French and 
Italian car manufacturers do not seem to have the same ability to attract industry in their proximity.

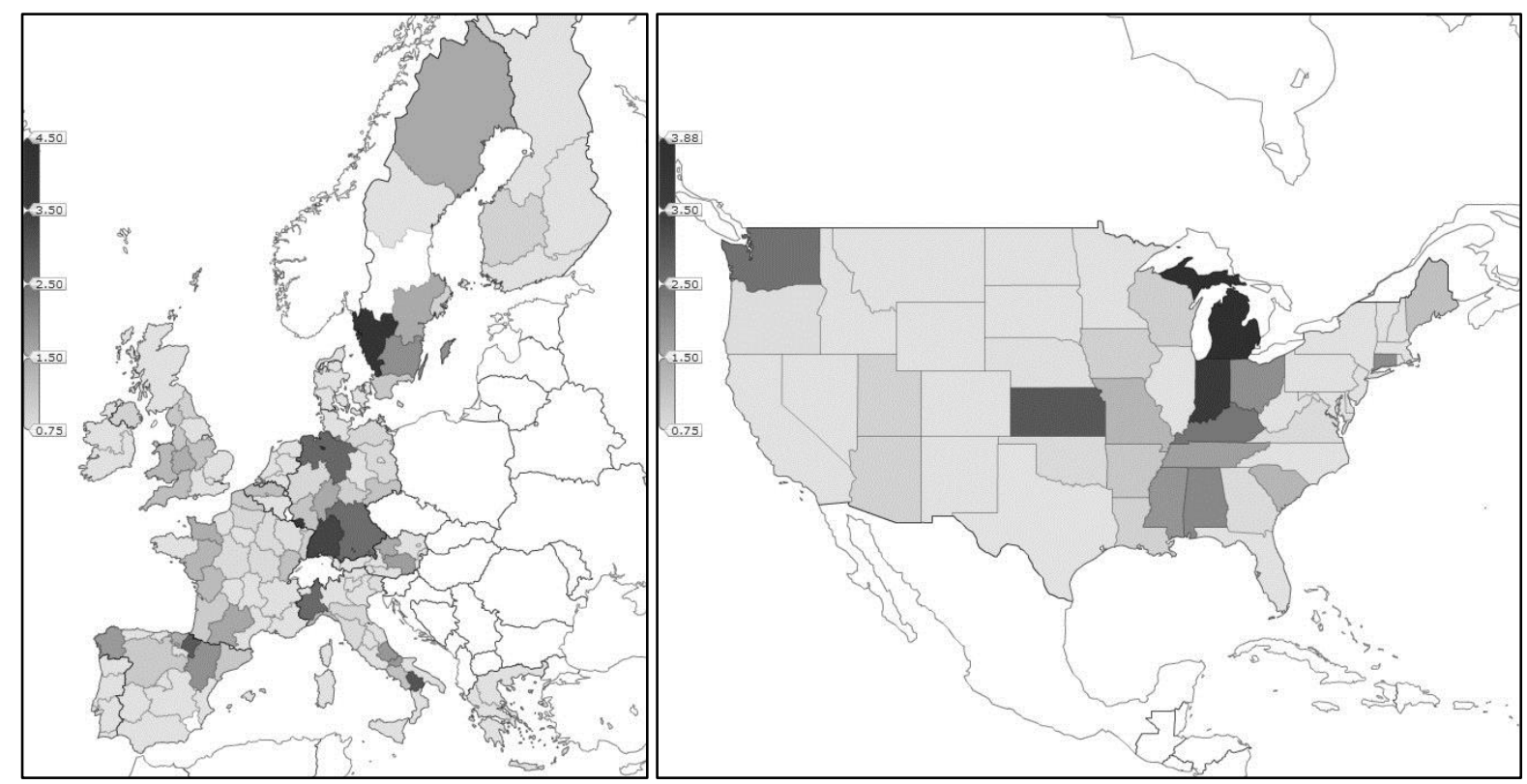

Figure 9: OECD eXplorer Maps, Transportation Equipment Manufacturing (Source: authors own calculations based on QCEW, n.d.; Eurostat, n.d.)

In the United States, the situation is similar. The highest BI (3.88) is reached in Michigan, the home of the Big Three in the automobile industry: General Motors and Ford in Motor-City Detroit and Chrysler in Auburn Hills. Runner-up is neighbouring Indiana with an Index of 3.58 and an above-average concentration can be observed all the way along a North-South route ending in Mississippi and Alabama at the Gulf of Mexico. Kansas (2.99) and Washington State, where almost half of Boeing's employees are located, (2.52) complete the table of states with significant Bls.

Contrary to the recent developments in the ICT sector's locations, the foundations for location decisions in the transportation industry have been laid around the beginning of the twentieth century. Rubenstein (1996) and Klier (1998) deliver an explanation for the choice of location of the US car manufacturers: proximity to the customer. Following Weber (1909), they conclude, that the automobile industry has always focused on minimising the costs of distributing the final product rather than the transport costs of the raw materials. In the past, this lead to a strategy of opening assembly plants throughout the nation in order to serve local markets. A dramatic reduction in output per model starting in the 1960s altered this landscape of dispersion. Diminishing economies of scale for single plants made it the first choice, to serve the entire market from one central location: the Midwest. The 
colocation of the Big Three stimulates the growth of many others choosing to locate closely and specialise in supplying the market giants. Institutions develop and the cluster's strength and visibility increases, leading to Porter's (1998) self-reinforcing circle of cluster growth.

The situation in Europe depicts the crucial factors in the location of the automotive industry. The highest Bls coincide with the headquarters of the big German car manufacturers in Southern Germany, which is a very central location for the Common Market of the EU. The peripheral location of the Italian, Spanish and - to a somewhat lesser extent - French car manufacturers might contribute an explanation for their inability to attract distinctive clusters. Strongly national images in the car industry 'tie' the European manufacturers to their respective home countries when perhaps a more central co-location could be better economically justified.

\section{Discussion}

It is evident from Table 3 that three out of the four observed industries are more concentrated in the European Union than in the United States. In the apparel and the primary metal industry, the European Locational Gini Coefficients 'beat' the American ones by five basis points; in computers and electronic products, the margin turns out considerably larger at 14 basis points. Only in the transport equipment industry, there are signs of a higher concentration in America, 'beating' the EU Gini Coefficient by five basis points.

\begin{tabular}{|c|c|c|c|c|}
\hline & \multicolumn{2}{|c|}{ European Union } & \multicolumn{2}{|c|}{ United States } \\
\hline & $\begin{array}{l}\text { Gini } \\
\text { Coefficient }\end{array}$ & $\begin{array}{l}\text { Location of Highly } \\
\text { Concentrated } \\
\text { Regions }\end{array}$ & $\begin{array}{l}\text { Gini } \\
\text { Coefficient }\end{array}$ & $\begin{array}{l}\text { Location of Highly } \\
\text { Concentrated Regions }\end{array}$ \\
\hline Apparel & 0.62 & $\begin{array}{l}\text { Southern European } \\
\text { Countries }\end{array}$ & 0.57 & $\begin{array}{l}\text { South (+ California and } \\
\text { New York) }\end{array}$ \\
\hline Primary Metal & 0.55 & $\begin{array}{l}\text { Northern Spain and } \\
\text { Northern Scandinavia }\end{array}$ & 0.50 & Midwest and South \\
\hline $\begin{array}{l}\text { Computer \& } \\
\text { Electronic Products }\end{array}$ & 0.67 & Ireland and Scotland & 0.43 & $\begin{array}{l}\text { Northwest and } \\
\text { Northeast }\end{array}$ \\
\hline $\begin{array}{l}\text { Transportation } \\
\text { Equipment }\end{array}$ & 0.43 & $\begin{array}{l}\text { Southern Germany } \\
\text { and Southern Sweden }\end{array}$ & 0.48 & $\begin{array}{l}\text { Midwest and South (+ } \\
\text { Kansas and } \\
\text { Washington) }\end{array}$ \\
\hline
\end{tabular}

Table 3: Summary of Results

Another impression given by the narrow analysis of four sectors is that the location pattern of the European economy as a whole resembles Midelfart-Knarvik's and Overman's (2002) 
image of "industry black holes": no pair of observed industries is located in the same regions. According to Midelfart-Knarvik and Overman, this occurs when gains through agglomeration are only present at industry level, rather than spilling over across industries. Quite surprisingly, this is even the case between the primary metal and the transportation equipment sector, where one would have expected a strong and positive relationship since metals are a major input for transportation equipment and volumes of transport are high and therefore costly. Comunidad Foral de Navarra in Northern Spain is the only region out of the 128 observed displaying Balassa Indices above 2.5 for both industries. In the United States, on the other hand, both industries are located in the North East, signalling stronger agglomeration gains across related industries. Avoidance of higher distances on the vast North American continent might be an explanation. The fact that two related industries do not choose to co-locate can be taken as a sign that obstacles to trade do not seem to play a crucial role in 2007 Europe - at least in this case.

The theory of the home market effect, (Ottaviano, 2004), seems to find more support in the US economy than in Europe. In the European Union, the advantages of regions with a considerably lower income level in attracting industries that depend on labour more than on innovations are obvious. Both the apparel industry and the primary metal sector are most densely concentrated in peripheral Europe, most likely for this reason. The location of the computer and electronic products sector in Ireland proves how the 'right' policies are able to attract industries. In spite of Ireland's peripheral location, most of the knowledge-intensive industry has settled down in the country, because the right incentives, such as a lucrative tax system and the provision of a highly qualified labour force and universities and other institutions, have been set in place. In the transportation equipment industry, the role that a couple of highly innovative market giants (the major car manufacturers) can play in laying the foundations for the formation of a cluster (Porter, 1998) is visible on both continents. The fact that in America the major car manufacturers happen to be co-located themselves might be an explanation for the higher Locational Gini Coefficients for the USA in that sector.

As previously indicated, the results, especially the quantitative comparison of Balassa Indices between the two continents, have to be taken with caution. In order for the data values to be completely comparable, the observed regions would have to be equal in size and 
population. Whenever this is not the case, the concentration in large regions will tend to be understated whereas the concentration in small ones will be overstated.

Amiti (1998) uses the same Gini Coefficient approach as this study, only with gross production values as input for her Balassa Indices. 17 out of the $27 \mathrm{EU}$ industries that she observed experience an increase in geographical concentration between 1968 and 1990, among them transport equipment (from 0.11 to 0.13 ) and wearing apparel (from 0.16 to $0.18)$.

Andaluz et al. (2002) choose a completely different approach. They work with Location Quotients on employment for US states and EU regions not to calculate Gini Coefficients, but probability distributions and Gaussian Kernels. Their study unites manufacturing activities into one broad manufactured product sector. They find that this sector is equally concentrated in the US and the EU, but contrary to many other studies, observe a trend towards higher concentration in America and no changes in Europe between 1980 and 1990.

Brülhart (1998) computes Gini Coefficients with industrial employment data on EU countries. He finds increasing Gini Coefficients for 14 out of his 18 observed industries between 1980 and 1990. In detail, he observes that labour- and resource-intensive industries (textiles, clothing and footwear) are shifting towards the EU periphery in exploitation of lower factor costs. Industries that are sensitive to economies of scale (motor vehicles) tend to agglomerate in the Centre. High-tech industries (data processing) have a tendency to clustering as well, but not necessarily in the economic core. All these findings are broadly in line with the results presented herein.

Most empirical and theoretical literature describes or predicts an increasing industry agglomeration within the European Union in the aftermath of the European Single Market Programme. This increase would partly explain why this study, though broadly in line with other empirical literature, observes, on average, a higher spatial concentration in EU industries. After all, in a dynamic economy like that of the European Union, a decade can provide a significant change in terms of industry concentration, especially when barriers to trade are abolished. Due to data availability, the TL2 regions have to be sacrificed as the unit of observation in this part of the study analysing trends. Country values are used instead. Location Quotients are computed in the familiar way for 1999, 2003 and 2007. 
Figure 10 illustrates the development of Location Quotients in the apparel industry for countries with high industry concentration (left) and low industry concentration (right). It can be seen that three out of the four Southern European states with Quotients above unity exhibit an increase in their already high concentration over the observed time period. All ten countries with Location Quotients below unity, on the other hand, exhibit decreasing Bls. This suggests that indeed an increasing apparel industry agglomeration takes place in the aftermath of the European Single Market Programme and partly explains the higher degree of concentration observed in this study in comparison to more dated literature.

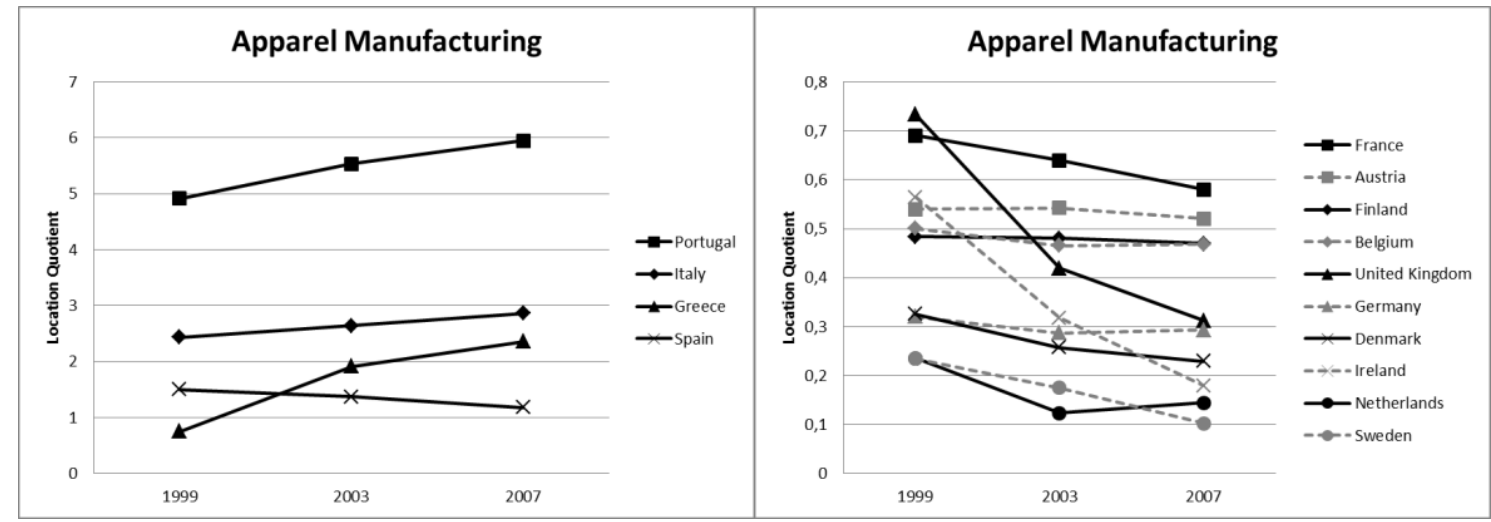

Figure 10: EU Location Quotients, Apparel Manufacturing 1999-2007 (Source: authors own calculation based on Eurostat, n.d.)

A similar trend of increasing agglomeration can be observed for the primary metal industry (Figure 11). Out of the six countries with Bls above unity, five exhibit an increasing concentration between 1999 and 2007. In the sixth country, Belgium, the BI only slightly decreases. Out of the remaining eight countries with sub proportionate industry shares only Greece features an increasing Quotient throughout the eight years, even though some more Quotients did increase in the last four years.

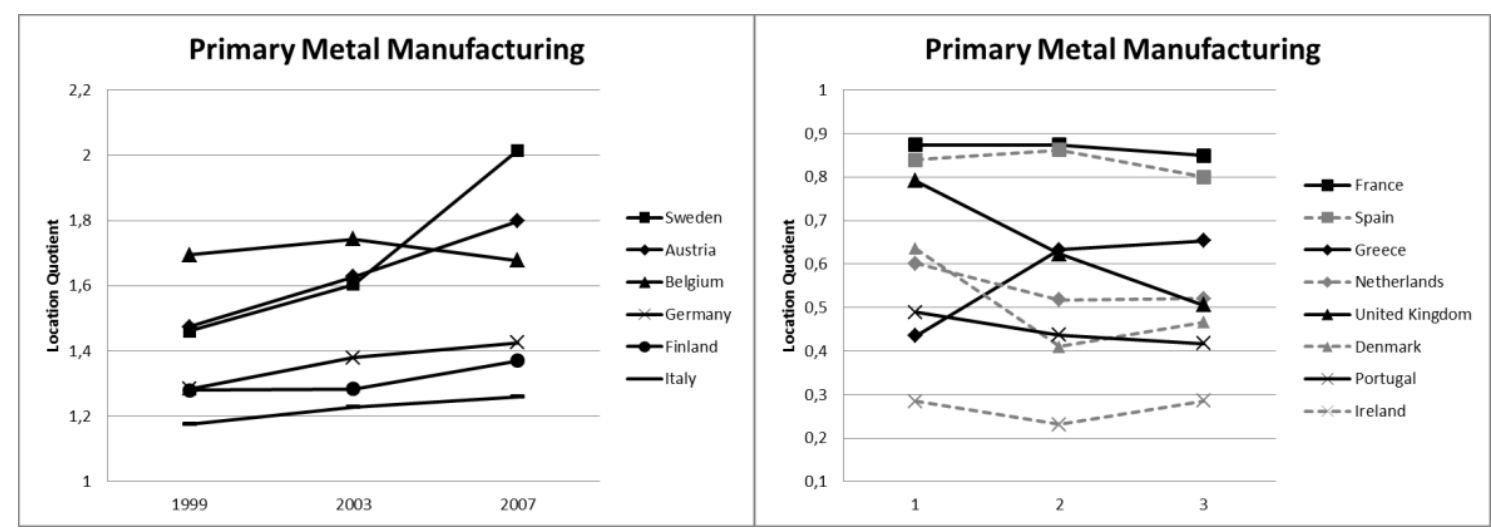

Figure 11: EU Location Quotients, Primary Metal Manufacturing 1999-2007 (Source: authors own calculation based on Eurostat, n.d.) 
In the computer and electric product industry (Figure 12), no tendency towards agglomeration or dispersion can be observed. For countries with Bls of one or lower, both upward and downward movement of Bls takes place. Ireland's level of concentration slightly decreased since 1999. This lack of dynamism can be explained by the current state of the industry. With Ireland's BI at 9.24, far above runner-up Sweden with 1.26, the industry already reached a level of extreme concentration. This stable equilibrium is hard to challenge.

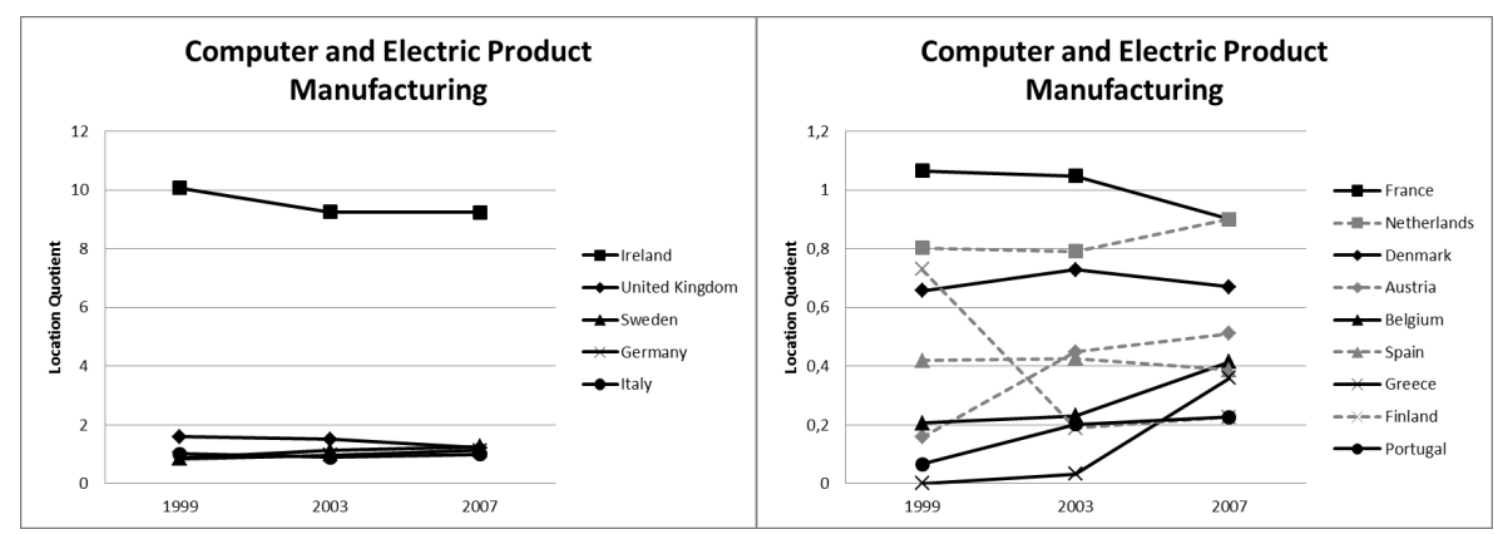

Figure 12: EU Location Quotients, Computer and Electric Product Manufacturing 1999-2007 (Source: authors own calculations based on Eurostat, n.d.)

Lastly, in transportation equipment manufacturing, the picture is similar to the first two industries (see Figure 13). The market leaders in terms of industry concentration, Germany and Sweden, strengthen their position through increasing industry concentration. Only France from the rest of the continent seemed as if it was about to challenge their position between 1999 and 2003, but the upward trend of the BI has eventually been reversed.

Three out of the four observed industries display an increase in agglomeration between 1999 and 2007. The fourth sector already exhibited an extremely high level of concentration. It seems that the European Single Market Programme has played its role in removing obstacles to intra-EU trade and thus has made it more attractive for industries to serve the entire EU market from one or two locations. 


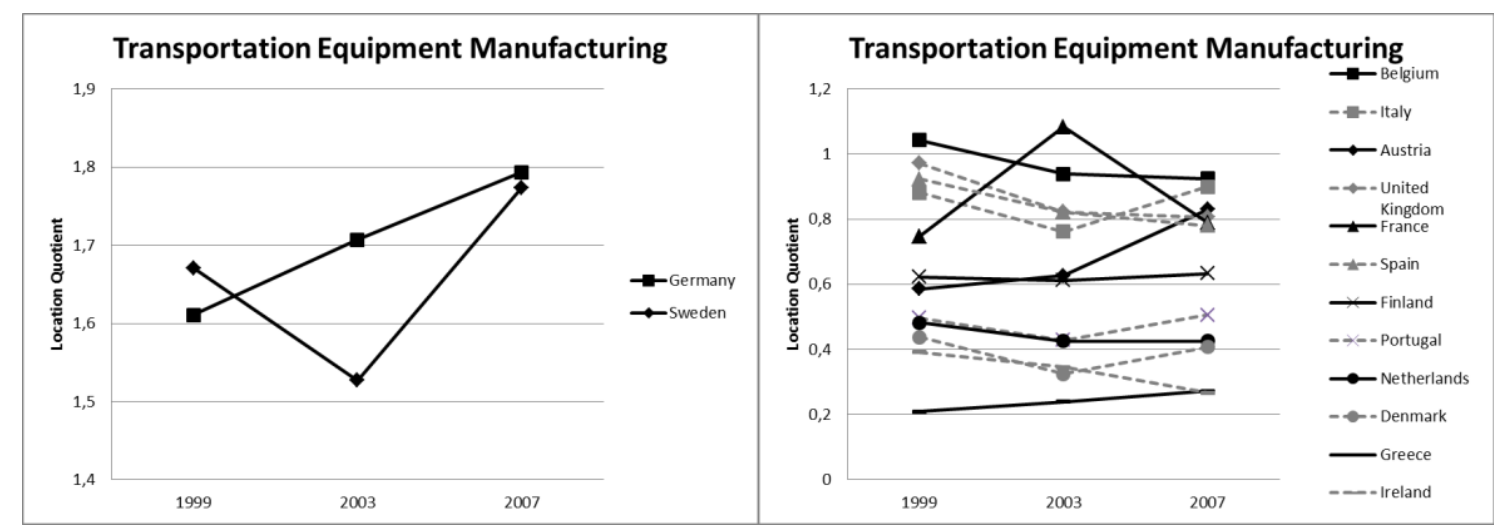

Figure 13: EU Location Quotients, Transportation Equipment Manufacturing 1999-2007 (Source: authors own calculations based on Eurostat n.d)

\section{Concluding Remarks}

This paper has investigated the location patterns of four manufacturing industries in the European Union and the United States. Locational Gini Coefficients have been computed alongside a more qualitative analysis of the spatial location of concentrated regions using choropleth maps. A key shortcoming of the classical approach has thus been simply addressed to some degree - that is the inability to distinguish between a geography in which highly concentrated regions are randomly spread across the country and one in which these regions are located close-by.

Much economic theory suggests that, ceteris paribus, an area which is more economically integrated (i.e. has lower barriers to trade) is expected to be characterised by a higher degree of spatial industry concentration. In most empirical literature from the 1990s, industries in the USA are found to be more agglomerated than their European counterparts, which suffer from considerable non-tariff barriers to trade within the EU. The fact that the results of this study suggest otherwise can be traced back to three reasons. Firstly, the ceteris paribus caveat is not valid. Instead, substantially higher wage gaps between European regions are likely to play a major role in two out of the four observed industries (cp. Puga, 1999). Secondly, a bias towards an overstated industry agglomeration in Europe was inevitable due to, on average, smaller populations in the European regions as compared with the US states. Thirdly, it is found that the European Single Market Programme has succeeded in diminishing non-tariff barriers to trade within the European Union and thus has increased the Union's degree of economic integration. 
Between 1999 and 2007 three out of the four observed industries have exhibited an increase in agglomeration. This seems tentatively supportive of the thesis of an increasing degree of industry agglomeration due to higher economic integration in the aftermath of the European Single Market Programme.

It remains hard to make strong inferences about the effects of economic integration on the spatial concentration of industries from an EU/US comparison due simply to the different sizes of economic regions and the fact that, in spite of all their economic similarities, some crucial differences do prevail and violate the ceteris paribus condition. Nevertheless, an increasing tendency towards agglomeration of industries in a merging European Union is suggestive of a positive relationship with further spatial concentration of industries to be expected.

\section{References}

Amiti, M. (1998). New Trade Theories and Industrial Location in the EU: A Survey of Evidence. In M. Jovanovic (Ed.), Economic Integration and Spatial Location of Firms and Industries - Volume3 (pp. 543-551). Cheltenham: Edward Elgar

Amiti, M. (1999). Specialization Patterns in Europe. In M. Jovanovic (Ed.), Economic Integration and Spatial Location of Firms and Industries - Volume3 (pp. 552-571). Cheltenham: Edward Elgar

Andaluz, J., Lanaspa, L., and Sanz, F. (2002). Geographical Dynamics: A Sectoral Comparison Between the Economic Landscapes of the United States and Europe. In M. Jovanovic (Ed.), Economic Integration and Spatial Location of Firms and Industries - Volume3 (pp. 635-648). Cheltenham: Edward Elgar

Balassa, B. (1965). Trade Liberalization and Revealed Comparative Advantage. Manchester School of Economic and Social Studies, 33, 99-123

Brülhart, M. (1998). Trading Places: Industrial Specialization in the European Union. Journal of Common Market Studies, 36 (3), 319-346

Bureau of Economic Analysis (BEA). (n.d.). An Introduction to BEA Regional Data. Retrieved January 11, 2010 from the BEA website: http://www.bea.gov/library/_pdf/regional_info.pdf

Bureau of Labor Statistics (BLS). (n.d.). Quarterly Census of Employment and Wages.

Retrieved August 12, 2010 from the BLS website: http://www.bls.gov/cew/

Combes, P., Mayer, T. and Thisse, J-F. (2008). Economic Geography: The Integration of Regions and Nations, Princeton N.J.: Princeton University Press 
Duranton, G. and Overman, H.G. (2005). Testing for localization using micro-geographic data, Review of Economic Studies, 72, pp. 1077-1106

Duranton, G. and Overman, H.G. (2008). Exploring the detailed location patterns of U.K. manufacturing industries using microgeographic data, Journal of Regional Science, 48, 213243

Eaton, C., and Lipsey, R. (1997). Introduction: Beyond Neoclassical Competitive Economics. In M. Jovanovic (Ed.), Economic Integration and Spatial Location of Firms and Industries Volume 1 (pp. 21-39). Cheltenham: Edward Elgar

Ellison, G.D., Glaeser, E.L. and Kerr, W.R. (2010). What causes industry agglomeration? Evidence from coagglomeration patterns, American Economic Review, 100, 1195-1213

European Commission. (1997). Summary, Review of the Theoretical and Empirical Literature, and Growth and Convergence Trends in Europe, 1975-93. In M. Jovanovic (Ed.), Economic Integration and Spatial Location of Firms and Industries - Volume3 (pp. 375-451).

Cheltenham: Edward Elgar

European Commission. (2010). List of NACE Codes. Retrieved August 10, 2010 from the European Commission website:

http://ec.europa.eu/competition/mergers/cases/index/nace_all.html

Eurostat. (n.d.). Regional Structural Business Statistics. Retrieved August 12, 2010 from the Eurostat website:

http://epp.eurostat.ec.europa.eu/portal/page/portal/european_business/special_topics/reg ional_structural_business_statistics

Feenstra, R., Markusen, J. and Rose, A. (1998). Understanding the Home Market Effect and the Gravity Equation: The Role of Differentiated Goods, CEPR Discussion Paper No. 2035

Green, R., Cunningham, J., Duggan, I., Giblin, M., Moroney, M. and Smyth, L. (2001). The Boundaryless Cluster: Information and Communications Technology in Ireland. In Organization for Economic Co-operation and Development (OECD) (Ed.), Innovative Clusters - Drivers of National Innovation Systems (pp. 47-64). Paris: OECD Publishing

Jovanovic, M. (2007). Economic Integration and Spatial Location of Firms and Industries Volume 1. Cheltenham: Edward Elgar

Kangasharju, A. (2001). Innovation Dynamics in Space: Local Actors and Local Factors. SocioEconomic Planning Sciences, 35 (1), 31-58

Klier, T.H. (1998). Geographic Concentration in US Manufacturing: Evidence from the US auto supplier industry (No. WP-98-17). Federal Reserve Bank of Chicago 
Krugman, P. (1999). The Role of Geography in Development. In M. Jovanovic (Ed.), Economic Integration and Spatial Location of Firms and Industries - Volume 1 (pp. 108-128). Cheltenham: Edward Elgar

Marcon, E. and Puech, F. (2003). Evaluating the geographic concentration of industries using distance-based methods, Journal of Economic Geography, 3, 409-428

Marcon, E. and Puech, F. (2010). Measures of the geographic concentration of industries: Improving distance-based methods, Journal of Economic Geography, 10, 745-762

Marshall, A. (1890). Industrial Organization Continued - The Concentration of Specialized Industries in Particular Localities. In M. Jovanovic (Ed.), Economic Integration and Spatial Location of Firms and Industries - Volume 2 (pp. 3-13). Cheltenham: Edward Elgar

Midelfart-Knarvik, K., and Overman, H. (2002): Delocation and European Integration: Is Structural Spending Justified? In M. Jovanovic (Ed.), Economic Integration and Spatial Location of Firms and Industries - Volume3 (pp. 506-542). Cheltenham: Edward Elgar

Midelfart-Knarvik, K., Overman, H., Redding, S., and Venables, A. (2002). The Location of European Industry. In M. Jovanovic (Ed.), Economic Integration and Spatial Location of Firms and Industries - Volume3 (pp. 452-505). Cheltenham: Edward Elgar

Mori, T., Nishikimi, K. and Smith, T.E. (2005). A divergence statistic for industrial localization, Review of Economics and Statistics, 87, 635-651

O'Donoghue, D. and Gleave, B. (2004). A Note on Methods for Measuring Industrial Agglomeration. Regional Studies, 38 (4), 419-427

Organization for Economic Co-operation and Development (OECD). (n.d.).Territorial Grids of OECD Member Countries. Retrieved January 11, 2010 from the OECD website:

http://www.oecd.org/dataoecd/19/29/43428422.pdf

Ottaviano, G. (2004). Footloose Capital, Market Access and the Geography of Regional State Aid. In J. Mucchielli and T. Mayer (Eds.), Multinational Firms' Location and the New Economic Geography (pp. 156-177). Cheltenham: Edward Elgar

Porter, M. (1998). Clusters and the New Economics of Competition. Harvard Business Review, November - December 1998, 77-90

Porter, M. (2003). The Economic Performance of Regions. Regional Studies, 37 (6-7), 549-578

Puga, D. (1999). The Rise and Fall of Regional Inequalities. In M. Jovanovic (Ed.), Economic Integration and Spatial Location of Firms and Industries - Volume 1 (pp. 237-268).

Cheltenham: Edward Elgar

Redding S. J. (2010). The Empirics of New Economic Geography, Journal of Regional Science, 50 (1), 297-311 
Rubenstein, J.M. (1996). The Evolving Geography of Production - Is Manufacturing Activity Moving out of the Midwest?: Evidence from the Auto Industry (No. SP-3). Federal Reserve Bank of Chicago

Schöler, K. (2005). Raumwirtschaftstheorie. Munich: Vahlen

Tian, Z. (2013). Measuring Agglomeration Using the Standardized Location Quotient with a Bootstrap Method, Journal of Regional Analysis \& Policy, 43(2), 186-197

U.S. Census Bureau. (n.d.). North American Industry Classification System (NAICS). Retrieved August 10, 2010 from the Census website: http://www.census.gov/eos/www/naics

Venables, A. (1994). Economic Integration and Industrial Agglomeration. In M. Jovanovic (Ed.), Economic Integration and Spatial Location of Firms and Industries - Volume1 (pp. 162178). Cheltenham: Edward Elgar

von Thünen, J. (1826). Der isolierte Staat in Beziehung auf Landschaft und Nationalökonomie. Hamburg: Pergamon

Weber, A. (1909). Über den Standort der Industrien. JCB Mohr 